\title{
Secondary Beginning Teachers' Views of Scientific Inquiry: With the View of Hands-on, Minds-on, and Hearts-on
}

\author{
Young-Shin Park*
}

Department of Earth Science Education, Chosun University, Gwangju 501-759, Korea

\section{과학탐구에 대한 중등 초임교사의 인식: Hands-on, Minds-on, Hearts-on의 관점으로}

\author{
박 영 신*
}

조선대학교 사범대학 지구과학교육과, 501-759, 광주광역시 동구 서석동 375

\begin{abstract}
The purpose of this study was to investigate beginning teachers' views of scientific inquiry envisioned in science education reform, which is the main goal of science education at schools. Teachers' views about scientific inquiry influence their students' learning in the classroom, so it is significant to investigate teachers' views about the scientific inquiry. 126 beginning science teachers participated in this study. The survey asking teachers' view of general scientific inquiry, nature of science (NOS) and the relationship of science, technology, and society (STS), was developed and implemented for 30 minutes. Alternative views of scientific inquiry including NOS and STS were emerged through data analysis with open coding system. The reliability and validity of data collection and data analysis were constructed through the discussion with experts in science education. The results of this study were as follows. Participants defined scientific inquiry as opportunities of 'Hands-On' and 'Minds-On' or its combination rather than 'Hearts-On'. However, teachers demonstrated the view of 'Hands-On' for the purpose of scientific inquiry and for teachers' roles in its implementation. The view of 'Hearts-On' about scientific inquiry was not identified. The naïve view of NOS were identified more than informative one. More positive attitude about the relationship of STS was released. The implication was made in teacher education, especially structured induction program for beginning teachers.
\end{abstract}

Keywords: scientific inquiry, beginning teacher, hands-on, minds-on, hearts-on

요 약: 과학교육의 목표인 과학탐구에 대해서 초임과학교사들은 어떻게 인식하고 있는지를 조사하였다. 교사의 과학탐 구에 대한 인식은 학생들의 과학탐구에 대한 인식에 영향을 미치는 것을 고려할 때 연구의 의미가 있다고 할 수 있겠 다. 126 명의 초임교사들을 대상으로 일반적인 과학탐구에 대한 인식과, 과학의 본성, 그리고 과학-기술-사회의 관계에 대한 인식을 파악할 수 있는 설문지를 개발하였다. 초임과학교사에 의한 과학의 본성과 과학-기술-사회 관계에 대한 인 식을 포함하여 전반적인 과학탐구에 대한 인식은 코딩작업을 통해 파악되었으며 이 과정을 통한 자료수집 및 분석의 타당성 및 신뢰성은 과학교육전문가와의 토론을 통해 구축되었다. 이 연구의 결과는 다음과 같다. 초임교사들은 과학탐 구를 실험적인 절차적 기술과 과학적 사고를 함양하는 기회로 정의하고는 있지만 과학탐구를 하는 이유와 과학탐구를 실행하는 데 있어 교사의 역할은 실험적인 절차적 기술을 함양하는 기회로 파악하고 있었다. 과학탐구에 대한 정의나 목적 또는 교사의 역할에 대해서는 정의적 영역에 해당하는 요소는 거의 파악되지 않았다. 과학의 본성에 대해서는 과 학적 관점보다는 순수한 관점으로 인식하고 있었으며 과학-기술-사회의 관계에 대한 인식은 긍정적인 태도를 보여 주었 었다. 초임교사를 위한 조직적인 교사교육을 개발할 필요가 있다.

주요어: 과학탐구, 초임교사, 절차적기능, 사고적기능, 정의적기능

*Corresponding author: parkys@chosun.ac.kr

Tel: $82-62-230-7379$

Fax: 82-62-230-7539 


\section{Introduction}

The purpose of science education is to achieve scientific literacy (AAAS, 1989; 1993; NRC, 1996; 2000). To meet the needs of scientific literacy at school, students will be able to learn scientific concepts, experience scientific inquiry skills where students understand knowledge's formation by promoting the understandings about NOS (Nature of Science) and the relationship of STS (Science, Technology, and Society), all of which are possible to be obtained through scientific inquiry teaching.

Scientific inquiry is defined operationally in this study with three Opportunities To Learn (OTL) as follows; students need to have chances to promote procedural inquiry skills from experimentation, which is called as OTL of 'Hands-On'. Students are reported that they performed significantly better through 'Hands-On' approach to science in mastering concepts (McCarthy, 2005). Chung (1998) reported that more physical experience through 'Hands-On' activity is pivotal in promoting students' concept understanding. Yang (2007) also analyzed the types of laboratory instruction in school science to report that there were verification and discovery types with the emphasis of student's physical experience through 'Hands-On' activity. Another OTL of 'Minds-On' is that students promote scientific thinking skills from argumentation through inquiry teaching. Skills in scientific inquiry tend to be recognized as technical and procedural skills only, however, thinking skills as well as procedural skills are operationally defined as scientific inquiry skills (NRC, 2000; Park, 2006). Bybee (2006) emphasizes the importance of thinking skills in the context of scientific inquiry and suggests that the components of inquiry are at the 'center of the learner's mental activity' (p. 9) and occur within a scientific context, with scientific goals and orientations, such as explanation building. Standards (NRC, 2000) stress students' opportunity of 'doing' during inquiry activity. That is, students promote scientific thinking skill by developing argumentation and procedural skills by carrying out the investigation. Osborne et al.
(2003) mentioned the use of creativity in scientific inquiry as a necessary thinking skill. Thinking or reasoning skills seem necessary to understand science and to do science. Kuhn $(1986,1993)$ added that students should have the capacity to think about their thought by developing the ability to coordinate their existing theories with new evidence they generate in an explicit and conscious way. Overall, students' thinking skills ('Minds-On') as well as procedural skills ('Hands-On') should be provided with opportunity for students to 'do' explicitly in the authentic environment created by teachers (NRC, 2000).

The last OTL of 'Hearts-On' is that students understand the nature of science including STS (NRC, 2000; Park, 2006). Standards (NRC, 2000) added one more definition of ideal scientific inquiry as 'understanding' about scientific inquiry besides 'doing.' 'Understanding' about scientific inquiry is the opportunity of 'Hearts-On'. Song and Cho (2004) described that Hearts-On can be the next paradigm of science education for the beginning of the $21^{\text {st }}$ century in that students need to be motivated in their science learning by knowing that scientific activities can be joyful. Song and Cho (2004) also released that science has become much important to modern life and society cannot exist at all without science. Students understand science as humanism. The main feature of 'Heats-On' can be illustrated as follows; students need to understand the core of science, to enjoy the joy of science, to feel the beauty of science, to experience the usefulness of science, to be aware of the responsibility of science, and to participate in the development of science (Song and Cho, 2004). 'Hearts-On' in science education is regarded as affective domain in science learning objectives, such as attitude about science, the nature of science and scientists as well as scientific knowledge (Lederman, 1992).

In summary, operational definition of envisioned scientific inquiry in this study consists of two categories; one is 'doing' and the other 'understanding'. 'Doing' consists of another two skills; one is procedural inquiry skill, 'Hands-On', and the other 
thinking skills, 'Minds-On'. 'Understanding' about scientific inquiry, 'Hearts-On', consists of two categories; one is NOS and the other STS. Each will be discussed in order.

Reform documents also consistently support the importance of students' possessing adequate understandings of NOS, which is also necessary to be learned explicitly to experience authentic scientific inquiry in the classroom (Khishfe and Abd-El-Khalick, 2002). The nature of science has been defined in numerous ways but it most commonly refers to the values and assumptions inherent to scientific knowledge. Lederman (1992) argues that there is no consensus concerning all aspects of the nature of science. However, reform documents and prior research in science education indicate that several aspects are assessable by K-12 science students and those are in the followings. 1) scientific knowledge is tentative (subject to change), 2) empirically based (based on and/or derived from observation of the natural world), 3) subjective (theory laden), 4) necessarily involves human inference, imagination, and creativity (involves and invention of explanations), 5) necessarily involves a combination of observations and inferences, 6) is socially and culturally embedded, and 7) involves a combination of the function of and relationship between scientific theory and laws. Many researches reported consensus that teaching NOS in the context of science instruction is very pivotal role for students to experience authentic scientific inquiry (Park, 2006).

With increasing need of thoughtful decision-making on controversial socioscientific issues in modern society, STS required fundamental changes to the status quo of science education and STS become pivotal goal in science education of scientific literacy for citizenship. As a way of promoting scientific literacy for citizenship, STS education has been widely practiced addressing value-laden socioscientific issues in classrooms.

So far, what scientific inquiry is and how it can be implement for the goal of scientific literacy at schools has been reviewed in this section. Learning and teaching science as inquiry is very essential for the purpose of scientific literacy but researches argued that science teachers who need to teach scientific inquiry showed the lack of knowledge in implementing scientific literacy in the classroom. Many researchers assume that teachers' knowledge and beliefs are automatically transferred to their practices of teaching science in the classroom, but they found that there is inconsistent between teachers' knowledge (or beliefs) and practices due to their unstructured knowledge (or beliefs), whose tendency is even worse in case of beginning teachers (Roehrig and Luft, 2006). Has been proposed the induction program where beginning teachers who are at the initial stage of teacher profession career can reflect on forming firm understandings about science as inquiry and being transferred into their practices of science teaching (Park et al, 2007; Choi et al., 2009; Crawford, 1999, 2000; Luft, 2001).

The purpose of this study is to investigate beginning science teachers' views/understandings about scientific inquiry, consisting of 'Hands-On', 'Minds-On', and 'Hearts-On' (Park et al., 2010; Song and Cho, 2004), which in turn influence students' views through explicit teaching strategies. When we assume that beginning science teachers' dualistic views (which is not fixed views about science teaching and learning, which is changing one resulted from dissonance between belief and practice, and finally which interfere teachers' professionals) and understandings of science teaching can conflict with their practices in the context of real teaching, it is very critical to know what are strength and weakness of beginning teachers' understandings and provide them with chance of reflecting on their understandings to be firmed and structured, later, aligned with their practices. This study is preliminary one which investigated teachers' views about scientific inquiry envisioned in the Standards (NRC, 2000) first, which will be the basis for the future study about teachers' practices aligning with their views/understandings.

The significance of this study reinforces the importance of induction programs for teachers and suggests that there is a need for specialized support 
Table 1. Survey for the view of scientific inquiry

\begin{tabular}{|c|c|}
\hline Region & Content/item \\
\hline View of SI & $\begin{array}{l}\text {-When you implement scientific inquiry activity in the classroom } \\
\text {-What objectives you meet during inquiry activity } \\
\text {-What teacher's roles are expected during inquiry activity } \\
\text {-Barriers of implementing scientific inquiry successfully } \\
\text {-Definition of SI (differentiation of three different types of inquiry: 'doing', 'teaching strategy', and 'understanding'. }\end{array}$ \\
\hline View of NOS & -Differentiation between theory and law \\
\hline View of STS & -The relationship among science, technology and society \\
\hline
\end{tabular}

programs for beginning science teachers. The study also provides specific suggestions for improving the preparation of secondary science teachers, especially, in the content of scientific inquiry.

\section{Methodology}

\section{The development of survey of view of scientific inquiry}

The researcher developed the survey of questions asking general views of scientific inquiry (SI) such as its definition, objective, teaching strategies, assessment, teachers' role, and barriers from students and physical environment. Participants were allowed to check the most appropriate overlapping responses. In addition, participants were asked to display specific views of SI, NOS, and STS. About SI, participants were asked to differentiate three types of scientific inquiry; one is scientific inquiry of 'doing,' where students have chances to frame question, make hypothesis, design investigation, and interpret data with the teacher's guidance by delivering the concept of 'evaporization'. The second is scientific inquiry teaching strategy delivering science concepts such as current, voltage, resistance, series connection, parallel connection, which students discovered by themselves with little teacher's help. The third is scientific inquiry of 'understanding', where students 'understand' the nature of science/scientist. Especially, two different questions about NOS were developed and participants were asked to differentiate theory from law with its relationship as well as its tentativeness. About STS, three different questions were developed and participants were asked to relate science with technology and society. The content validity of survey was constructed through discussion with experts in science education. All surveys were collected for the researcher to develop categories through coding system when necessary. The validity and reliability of data analysis were also constructed through discussion with expert in science education. Items in the survey are described briefly in Table 1 . In view of SI, participants in this study responded to the first 4 questions as multiple choices and defined SI as different ways in the format of open ended questions.

\section{Data collection and data analysis}

126 beginning science teachers participated in this study and responded one survey which was developed by the researcher. 126 participants were contacted by the researcher through convenience sampling. 4 volunteers were further interviewed and they provided more detail information and examples of certain questions. The average teaching period of 126 participants was 4.22 years and only 3 participants took professional development program related to scientific inquiry, such as experimentation or equipment tools. The survey lasted for 30 minutes in the classroom of university. All participants were teaching 'general science' at high school.

The statistical comparison among participants' responses in each item was employed to illustrate the view of SI displayed by participants with the detailed description from the furthered interview protocols.

\section{Results}

The view of scientific inquiry including aspects of 
NOS and STS was described on the basis of survey responded by 126 participants as follows.

\section{Definition of scientific inquiry}

126 participants in this study were asked to make decision in which classroom scientific inquiry activity is taking place on the basis of given scenarios. Those scenarios were adopted from Bybee (2000) (Appendix) and he introduced three different types of inquiry activity, where students have chances of promoting thinking abilities through experimentation, learning science concepts, and understanding of inquiry. The first classroom inquiry activity provided students with chances to experience procedural and thinking skills, the second to learn science concepts directly through inquiry teaching strategy, and the third to experience the nature of science and scientific knowledge. All three classroom activities were considered as inquiry ones with different purposes in Bybee (2000). All of 126 participants selected the first classroom as the most preferred inquiry activity to the question of which one is inquiry happening. Majority of them (109 of 126 participants) were confident that scientific inquiry was happening in the first classroom since students experienced science processes of framing questions, investigating, and interpreting the data through trial and error (Table 2).

However, those participants displayed the lack of understandings of scientific inquiry in the other two classrooms. $52 \%$ of participants considered activity in the second classroom as inquiry one because of students' physical experience. However, students' experience in the second classroom is different from that of first classroom in that there is no framed question to be explored. Students in the second classroom just explored electric circuit installation and tried to light the bulb as requested by a teacher.
Students could light the bulb as twice strongly as possible without the concept of voltage, current, resistance, parallel or series connection, all of which were introduced by a teacher at the end of the activity. The purpose of scientific inquiry in the second classroom was for students' learning several concepts related to electric circuit by trying to light the bulb or twice as strong. However, teachers in this study considered students' physical experience only as to be one of conditions releasing the aspect of inquiry. $42 \%$ of participants also responded that the third classroom as inquiry one due to students' indirect experience of science processes from reading scientists' autobiography. Both of reasons, students' direct physical experience in the second classroom and indirect physical experience from reading in the third classroom, were resulted from teachers' traditional and typical understandings about scientific inquiry (Krajcik et al., 1998; Kwak, 2009). Overall, participating beginning teachers displayed the traditional view of scientific inquiry, 'Hands-On', mainly in three cases of classroom when questioned.

Participants perceived scientific inquiry with various views as follows. $42 \%$ of total responses (50/total 120 responses) defined scientific inquiry as chances of scientific thinking experience ('Minds-On'), 30\% of total responses (36/120) as one of ways for conceptual understanding through experimentation ('Hands-On'), and $13 \%$ of total responses $(15 / 120)$ as logical and reasonable methods ('Hands-On' \& 'Minds-On') to understand the natural phenomena, which could make participants select the first classroom as the most preferred inquiry in terms of 'Hands-On' or 'MindsOn' view (Park, 2010; Song and Kim, 2004) in Table 3. In addition, other responses about scientific inquiry include; solving the problem from curiosity (11/120; $9 \%)$, creative activity $(3 / 120 ; 3 \%)$, learning concepts

Table 2. Responses about different types of inquiry

\begin{tabular}{cccccccc}
\hline \hline & \multicolumn{2}{c}{ Classroom 1 } & \multicolumn{2}{c}{ Classroom 2 } & \multicolumn{2}{c}{ Classroom 3 } \\
\hline \multirow{2}{*}{ \# of } & Yes & 109 & 87 & 65 & 52 & 53 & 42 \\
responses & No & 13 & 10 & 48 & 38 & 58 & 46 \\
Percent (\%) & N/A & 4 & 3 & 13 & 10 & 15 & 12 \\
\hline
\end{tabular}


Table 3. Definition of scientific inquiry by participants

\begin{tabular}{lcc}
\hline \hline \multicolumn{1}{c}{ Definition of scientific inquiry } & Response & (\%) \\
\hline Students develop better understandings about concept through 'Hands-On' activity. & 36 & 30 \\
Logical and reasonable methods to understand the nature phenomena & 15 & 13 \\
plan investigation and solve the problem through scientific thinking as real scientists do & 50 & 42 \\
Autonomous discovery learning & 1 & 1 \\
All activities related to science including experimentation, discussion, and the process to solve the problem & 1 & 1 \\
Creative activity based on actual observations & 3 & 3 \\
Teaching strategies for conceptual understandings & 1 & 1 \\
The process to understand scientific principles through cooperative learning or discourse & 2 & 2 \\
The process to solve the problem from curiosity and interest & 11 & 9 \\
\hline \multicolumn{1}{c}{ Total } & 120 & 100 \\
\hline
\end{tabular}

through interaction like discourse $(2 / 120 ; 2 \%)$, teaching strategies (1/120), and discovery learning (1/ 120).

Overall, teachers perceived scientific inquiry as various ways to the open ended question of its definition, some of which envisioned in Standards (1996, 2000), while they displayed the view of scientific inquiry in terms of 'Hands-On', typical but traditional view, in responding to three different scenarios offered to them. Participants in this study also displayed view of 'Minds-On' about scientific inquiry but not 'Hearts-On'. The following example is describing alternative views of beginning teachers participating in this study about scientific inquiry. Kim, female teacher, was in the middle of forming extended or new views about scientific inquiry. Kim typically perceived that there must be steps in scientific inquiry like algorithms but she also held the view that discussion itself without experimentation during the class could be the inquiry lesson if students have chance of practicing thinking skills.

I thought that inquiry starts with curiosity. Curiosity makes students design the investigation to find the answer to question raised by curiosity. Investigation consists of sequential stages. However, I became to think of another possible inquiry lesson through which students can discuss the issue by practicing logical thinking skills (Kim).

Kim displayed the firm view of scientific inquiry in terms of 'Hands-On', releasing another view in terms of 'Minds-On'. Kim seemed to extend her view of scientific inquiry by adding 'Minds-On' to 'HandsOn'. This is one of cases of one beginning teachers' forming new and extended view of scientific inquiry. Some contextual factors, such as taking professional development program, can account for Kim's forming newly extended view.

In Table 3, students' opportunities of thinking process $(42 \%)$ were most preferred by participants as one of definitions of scientific inquiry, instead of experiencing experimentation (30\%), which explained why inquiry does not happen in the second and third classroom scenarios because there is NOT chance for thinking process (24 responses out of $89 ; 27 \%$ ) (Table 4). Other responses about why inquiry is not happening in the classroom include as follows; 19 participants out of 89 responded that there is no stage to develop hypothesis (21\%) and this is not inquiry happening. Kim believed that students do not carry out inquiry activity without making hypothesis in the following interview. She replied that students in the second classroom scenario only 'do' make trial and error to light the bulb without hypothesis leading this activity.

I thought that students need to have chances to develop hypothesis for inquiry, but students in the second classroom do not have chance to develop hypothesis, they only make trial and error to make the bulb lit (Kim).

Teacher Jeong also held the view that no inquiry activity is possible without guiding inquiry question. The big difference between the first and second 
Table 4. Reasons of NOT-inquiry in the classroom

\begin{tabular}{lcc}
\hline \hline \multicolumn{1}{c}{ The reason why it is NOT inquiry room } & Response & $\%$ \\
\hline Students' attitude is passive and the answer is given by teachers. & 13 & 15 \\
No scientific thinking process. Only summarize the content & 24 & 27 \\
no activity to collect actual data nor actual observation & 10 & 11 \\
no interaction with teachers & 1 & 1 \\
no conceptual development & 8 & 9 \\
only confirm the results through experimentation & 14 & 16 \\
no stage to develop hypothesis, nor investigate, nor test & 19 & 21 \\
\hline Total & 89 & 100 \\
\hline
\end{tabular}

scenarios was if there was guiding inquiry question or not, releasing Jeong's view of scientific inquiry as one cycle, holistic way, starting from framing question to concluding the results at the end.

Students identify one question which they will explore. No investigation can be possible without identified inquiry questions. So I think the first classroom is perfect situation for students to do scientific inquiry. It is that funny for students to observe something without any motivated question? Framing questions from curiosity is the first thing to do in inquiry activity (Jeong).

In addition, other views in Table 4 . why beginning students think that there is no inquiry happening in the classroom include; students only confirm the results through experimentation $(14 / 89 ; 16 \%)$, students are passive in their 'doing' with the answers given by teachers $(10 / 89 ; 11 \%)$, there is no conceptual development $(8 / 89 ; 9 \%)$, nor interaction $(1 / 89 ; 1 \%)$.

On the basis of results of Table 3 and Table 4 , the general definitions about scientific inquiry are reflecting the spectrum of 'Hands-On' and 'Minds-On' views perceived by beginning science teachers without views of 'Hearts-On', where students could understand the nature of science, scientific knowledge, or scientist. Overall, beginning teachers participating in this study viewed scientific inquiry as the process of experiencing scientific thinking ('Minds-On') as well as experimenting ('Hands-On'). Teachers could list the stages of scientific inquiry from framing questions or making hypothesis to interpreting the data, but they could not display what exact thinking process are involved scientific thinking process. Teachers could only use the term of 'thinking' or 'logics' but they were not confident what logical thinking is, nor is what critical thinking when interviewed.

\section{Teachers' role in doing scientific inquiry}

Participants were asked to list the teacher's role in guiding students' inquiry activity based on their experience. The most preferred teachers' roles were 'problem solver' (89/237 responses; 38\%) and 'information provider' $(75 / 237 ; 32 \%)$ rather than 'evaluating inquiry process' $(45 / 237 ; 19 \%)$ or 'mediating conflicts' among students (28/237; 12\%). The first two roles can be interpreted as the results from more focusing on science as a product and the last two roles on science as a process in Table 5.

Most participating teachers believed that playing roles of providing information and solving the problems make inquiry activity successful, but mediating students to discover the concept by themselves through discussion is also identified by a few teachers as another teacher' roles. Kim in the following interview displayed that teacher' roles as

Table 5. Teachers' roles in scientific inquiry classroom

\begin{tabular}{cccccc}
\hline \hline & Mediator & Solver & Provider & Evaluator & Total \\
\hline Frequency & 28 & 89 & 75 & 45 & 237 \\
$\%$ & 12 & 38 & 32 & 19 & 100 \\
\hline
\end{tabular}


mediating students' ideas rising rather than giving direction are more important in students' inquiry activity.

In the first classroom scenario, the teacher did not provide exact science concept until the end of activity. Students had chance to frame questions, make hypothesis, design the simple investigation, and share their opinions after experiments. During all activities, teacher did not direct students to do something. The teacher in that scenario only guided students to get their direction and mediate students' alternative ideas rising (Kim).

\section{Objectives of scientific inquiry}

Beginning teachers participating in this study identified the objectives of scientific inquiry as follows. The most preferred objective of scientific inquiry were developing students' inquiry skills (86/ 353 responses; 24\%), motivating students' interest in learning $(84 / 353 ; 24 \%)$, and enhancing conceptual understanding $(81 / 353 ; 23 \%)$. On the other hand, students' cultivating expressivity (10/353 responses; $3 \%$ ) as well as improving communication skill (21/ $353 ; 6 \%$ ) were the least preferred objectives for teachers to implementing scientific inquiry in the classroom (Table 6).

When teacher Park, one of interviewees, was asked of what she expected students to learn during inquiry activity, she responded that students need to learn procedural skills during experimentation, since most activities in the textbooks were confirmation ones and it was impossible to implement open inquiry due to time limitation and class size.

Table 6. Objectives of scientific inquiry in the classroom

\begin{tabular}{|c|c|c|}
\hline Objectives of Scientific Inquiry & Response & $\%$ \\
\hline Promoting students' higher order thinking skill & 40 & 11 \\
\hline Enhancing conceptual understanding & 81 & 23 \\
\hline Improving communication skill & 21 & 6 \\
\hline Motivating students' interest in learning & 84 & 24 \\
\hline Fostering logical attitude for science & 31 & 9 \\
\hline Developing inquiry skills & 86 & 24 \\
\hline Cultivating expressivity & 10 & 3 \\
\hline Total & 353 & 100 \\
\hline
\end{tabular}

Confirmation inquiry in the textbooks is good for students to practice procedural skills, and it is good to motivate students though students can do the same that scientists do at their research sites (Park).

Teacher Park added that she gave structured questions so that students could think scientifically during inquiry activity.

I questioned students when I want them to think scientifically. One example, I asked students to find out how salmon can return instinctively to their birthplace. Then they did not know how to answer. They kept so quiet. But when I start to ask concrete questions, such as how can I track salmon? How can I detect them? Attaching a tag? Ribbon? Then they began to talk with mates (Park).

Overall, it can be interpreted that teachers' objectives of implementing scientific inquiry in the classroom include students' opportunities of learning concept, encouraging students' motivation, developing thinking skill as well as procedural skill, and improving communication skill, however, no objective of implementing scientific inquiry reflect the view of understanding the nature of science or scientific knowledge, which are the view of affective domain, 'Hearts-On'. Beginning teachers do not hold the view of scientific inquiry in terms of 'Hearts-On'.

\section{Barriers for scientific inquiry}

Barriers identified by participants in implementing scientific inquiry divided into two components; one is variable of students as learners and the other one of physical environment.

The most interfering barrier identified by students (Table 7) was their social skills in group work (71 of 202 responses; 35\%). The other interfering barriers of students' carrying out inquiry activity include; students' uncomfortable attitude to do scientific inquiry (49/202; $24 \%$ ), their irresponsibility of playing assigned roles in group inquiry activity (41/202; 20\%), and students' lack of scientific knowledge $(40 / 202 ; 20 \%)$. One teacher also commented that no sense of purpose of 
Table 7. Barriers from variable of students as learners in implementing scientific inquiry

\begin{tabular}{lcc}
\hline \hline \multicolumn{1}{c}{ Barriers } & Response & $\%$ \\
\hline Students do not play their assigned roles well & 41 & 20 \\
Students show the lack of practicing social skills & 71 & 35 \\
Students show the lack of understanding concepts in subject matter & 40 & 20 \\
Students feel uncomfortable in carrying out the investigation due to the time limitation in spite of their interest. & 49 & 24 \\
Students do not know what they are doing (no objective of doing inquiry) & 1 & 0 \\
\hline \multicolumn{1}{c}{ Total } & 202 & 100 \\
\hline
\end{tabular}

doing inquiry is another barrier for inquiry activity.

Participants viewed that cooperative learning and group work are critical in carrying out scientific inquiry activity, but the students' immature social skills and their irresponsibility make inquiry activity from being implemented successfully. The following quotation from teacher Ryu expressed that students' social skills in grouping is critical to make inquiry activity successful as she intentioned.

When grouping, I try to make groups heterogeneous with three or four students but one of them need to have a tendency to be inclusive leader rather than alienating. If one student in groups plays a role of inclusive leader in guiding students' activity and opinions to be shared, I can observe those activities end successfully. However, if there is not certain leader who plays a role of guiding activity but plays a role of alienating, then the group activity ends with failure (Ryu).

In addition, students' attitude about science is another important factor influencing on their learning science as inquiry. Once students have interest in science and show motivation about learning science, they are willing to be engaged in inquiry activity with full passion.
It is odd. Though some students are high achievers, they are observed to be less engaged in inquiry activity, while others who are low achievers are more actively engaged in inquiry activity. I think students' scientific knowledge is not pivotal in their successful science learning as inquiry; instead their attitudes about science including motivation and interests are pivotal in meaningful science learning as inquiry (Jeong).

The most interfering barrier from physical environment variable was that there is no enough time for beginning teachers to implement/carry out scientific inquiry activity successfully (72 of 256 responses; $28 \%$ ). Other physical environmental barriers include; teachers show the lack of understanding of pedagogy content knowledge (PCK) of teaching science through inquiry activity $(64 / 256 ; 25 \%)$, there is no enough time for teacher to develop well-planned inquiry activity $(54 / 256 ; 21 \%)$, there are not enough data source to get the idea, nor computers to use, nor wellorganized desk $(39 / 256 ; 15 \%)$; and it is difficult to develop appropriate theme for 'doing' scientific inquiry $(22 / 256 ; 9 \%)$. Other barriers (5 responses) include the issues of class size, overload for teachers besides teaching itself, and too much content to cover during the academic year (Table 8).

Table 8. Barriers of physical environment variable in implementing scientific inquiry

\begin{tabular}{|c|c|c|}
\hline Barriers & Response & $\%$ \\
\hline There is no enough time in developing well-prepared inquiry activity & 54 & 21 \\
\hline There is no enough time in carrying out inquiry activity during class. & 72 & 28 \\
\hline It is difficult to develop appropriate theme for "doing" scientific inquiry. & 22 & 9 \\
\hline Teachers show lack of professionals in teaching strategies (no knowledge how to implement scientific inquiry) & 64 & 25 \\
\hline There are not enough data source, computers, and desks. & 39 & 15 \\
\hline Other & 5 & 2 \\
\hline Total & 256 & 100 \\
\hline
\end{tabular}


Most participating teachers responded that they had never been taught of how to teach scientific inquiry and they had little learned of how to teach it. All participating teachers showed positive response that they are willing to attend the workshop of scientific inquiry if offered on the basis of survey analysis. Participating teachers responded that the following factors must be considered to create authentic environment where teachers and students explore meaningful inquiry activity; extending science block time, promoting equipment at school, assigning lab assistant, attending inquiry professional development program, developing work-samples of inquiry, supporting finances for inquiry activity, reducing class size, grouping students heterogeneously, collaborating other teachers to share ideas, preparing students with content knowledge, etc.. More than anything else, participating teachers appeal to teacher professionalism of scientific inquiry and its PCK for the successful implementation of scientific inquiry activity in the classroom.

\section{View of nature of science (NOS) and science-technology-society (STS)}

Beginning teachers' views about the difference between scientific theories and scientific laws were identified as follows. Majority of participants displayed naïve views rather than informative ones about NOS. Scientific theory is viewed by participants as follows; scientific knowledge is what is not proven, explains the phenomenon, which also has exception in some cases, and which is changeable from instability to be firm like scientific laws. Scientific law is viewed as scientific knowledge which is always proven, which is true in all cases without any exception, which is unchangeable absolutely, and which is from theory through empirical processes. Majority of participating teachers who displayed naïve concept of NOS responded that they had never been told and taught about NOS during their teacher preparation program or other teacher professional development program. The following quotation is from Kim teacher's interview and she displayed naïve view about NOS.
I thought that theory is middle one to be law which is absolute and applied without exception to natural phenomenon. That is, plate tectonics is theory and evolution is another theory, but I thought that they will become laws later. But I found that there are theory, law, and principle with the same concept, which is Avogadro. There is Avogadro theory, Avogadro law, and Avogadro principle, which make my understanding and science concept mingled. It is embarrassing (Kim).

However, some beginning teachers expressed their willingness to learn NOS since their understandings influence those of students in learning science as inquiry. In case of teacher Ryu, she believed that students should know psychological aspect of NOS, which means, it is necessary for students to know that scientists must be ethical and moral in making decision scientific issues encountered in their life. When students understand the ethics of science, she was confident that students could experience the aspect of scientific inquiry. It was impressive view that teacher Kim expressed herself that it is ideal for students' scientific inquiry to be assessed through national examination and for preservice teachers' one through teacher evaluation test in Korea, which is believed to prove that teaching science as inquiry in the classroom should include all aspects of scientific inquiry, named as 'Hands-On', 'Minds-On', and 'Hearts-On' (Park et al., 2010). The following quotation put the emphasis of NOS.

I think that ethical aspect of science and nature of science must be tested at least in one question of National Teacher Evaluation Test (NTET). Or teacher candidates must be interviewed at the final stage of NTET to assess how much those candidates are ready to teach NOS and scientific ethics to students (Jeong).

About the relationship among STS, beginning teachers (73 of 126 participants; 58\%) participating in this study believed that there are intimate relationships among science, technology and society, which play roles of cause-effect relationship each other. That is, 
teachers believed that science influences technology, which in turn influence society in a sequence. $20 \%$ of participating teachers (25/126 participants), however, responded that science is more natural science which discovers the knowledge of the phenomena from skepticism rather than applied science essential to human life. They did not relate science to society or technology. About the impact of science, $69 \%$ of participants $(87 / 126)$ responded that there is positive impact of science development in that science can produce solution to certain scientific and environmental problems, and $17 \%(21 / 126)$ its negative impact on society in that science is the main factor causing climate change. About the differentiation between science and technology, 39\% participants (49/126) differentiated science from technology; however, $44 \%$ (56/126) participants did not. There were a few teachers who knew why and how they teach STS during science learning as inquiry even though all participants agreed that it is important to teach STS for scientific inquiry, proving that they showed the lack of knowledge about STS. The following quotation is from Kim and she showed her trial to make students understand the relationship of STS in her class.

I sometimes ask students if they can find that is not related science in their life. Students would name materials unrelated to science. Then I made the point of science's role in our life, that is, even in politics, I told students that we could find science process in making decision. I also told them that we can find "science" in everywhere. I add ethics in science when I talk about STS (omitted). With one science, we can kill people and we can save lives. For example, ammonia is the best one, which was used to kill Jewish people but used to produce commercial fertilizer to save lives in the world (Kim).

Overall, participating teachers in this study held the more view of naïve rather than informative one about scientific laws and theories. Teachers also held that the view of science is natural one from skepticism, social one to understand its role in society, and science has more positive influence on technology. On these views, they also showed willingness to have opportunity to reflect on their understandings of NOS and STS to be promoted into informative ones as long as teacher professional program would be offered.

\section{Discussion and Implication}

On the basis of the results in this study, the following remarks can be concluded. First, it is very critical for beginning teachers to have chances of reflecting on their unstructured beliefs and knowledge about scientific inquiry to meet the goal of implementing scientific inquiry activity envisioned in science reform. The results of this study showed that beginning teachers displayed the view of ' $\mathrm{Hands}-\mathrm{On}$ ' and 'Minds-On' about scientific inquiry in its definition but they displayed more 'Hands-On' view in its objectives of implementing scientific inquiry in the classroom. In addition, teachers had more emphasis of teachers' role as information provider and problem solver, which are more connected to 'Hands$O n$ ' view, rather than evaluator or mediator, connected to 'Minds-On' view of implementing scientific inquiry. We have very limited chances for novice teachers to have their envisioned understandings formed and changed through induction program in this country. Many researches have been reporting that teachers who hold the firmed and structured can make their understandings embedded in their practices of teaching science as inquiry in the classroom (Luft, 2001; Roehrig and Luft, 2006). Therefore, beginning teachers should be provided with opportunities to reflect on their understandings and practices, which, in turn, can be firmed to be consistent with their teaching practices of scientific inquiry. The systematic induction program needs developing with the aim of teacher professionalism and initializing more productive teacher career. In addition, more contextual factors must be considered to encourage beginning teachers to be concentrating on students' engagement in meaningful science activities with the scaffolding by mentor teachers at school (Adams and Krockover, 1997; Choi et al., 
2009). It has been reported that beginning teachers make effort to conduct the research into their practices of teaching science as inquiry in learning communities where they could interact with mentor teachers or educators (Bianchini and Cavazos, 2007; Roehrig and Luft, 2006; Kwak, 2009). More than anything else, all participants in this study showed their willingness that they would attend workshop of scientific inquiry if offered to have opportunities of reflecting on their prior views and practices to be integral with other factors rising in real context of teaching in the classroom. It is strongly recommended that we need to provide induction program where beginning teacher experience all kinds of success and struggles to be professionals in their science teaching. It might be best for beginning teachers to experience induction program housed at their schools, where they could become experts in science teaching while they interact with physical environment such as students, school context, and parents as well as other teachers (Bianchini and Cavazos, 2007).

Second, explicit teaching strategy by teaching history of science is considered as the most effective for students to learn scientific inquiry as the view of NOS and STS (Abd-El-Khalick and Lederman, 2000; Abd-El-Khalick et al., 1998). The results of this study showed that teachers held the naïve views of NOS in that scientific law is too absolute to be changeable and scientific theory is tentative. They also released unstructured view of STS in that science influence technology which in turn influences society in a sequence rather than interaction among these three components. Therefore, more structured professional program needs to be exposed to beginning teachers for them to explore what NOS and STS are and how they relate. Some participants expressed preference to employing teaching strategy of history of science when teaching science as inquiry, where teachers can provide students with opportunities of experiencing nature of science and the interaction among science, technology, and society. In case of teacher Ryu, she found that students have more interest in learning science when employing teaching strategy with the use of history of science. Teacher Ryu also stated that students who are not interested in science tend to be motivated when ethical and social aspects of scientists were introduced. Research has shown that aspects of NOS and STS through history of science can be understandable by students through its explicit/ reflective instruction (Abd-El-Khalick and Lederman, 2000; Khishfe and Abd-El-Khalick, 2002; Smith et al., 2000). It is suggested to develop explicit/reflective teaching strategy, if possible through history of science, for teachers to learn and employ it in teaching science as inquiry through teacher preparation program and induction as well.

To make this induction program successful, beginning teacher need to be ready to experience dissonance coming from inconsistency between theory and practices. Before entering real context of teaching to experience dissonance, preservice teachers should have appropriate chances of learning the envisioned objectives of scientific inquiry through teacher preparation program at university. Most beginning teachers were not sure of teaching science as inquiry since they had never been taught of how to teach it! The systematic teacher preparation courses at universities need to be offered to preservice teachers who can fully experience all aspects of scientific inquiry theoretically and practically so that they can at least experience the dissonance or dualism from theory obtained at universities and practices offered at schools. More than anything else, teachers reflect on their understandings and practices enough to feel necessity to change understandings to be met with practices. A few teachers displayed that they go back or keep the original concept if they are not allowed to reflect on their theory into the practices long enough and if those theoretical concepts are not anchored into their minds.

Future studies are expected as follows; how teachers' understanding about scientific inquiry affects their teaching in the classroom and how mentor teachers can help mentees to enhance teachers' understanding and practices about scientific inquiry through learning communities housed at schools. 


\section{Acknowledgment}

I would like to thank two anonymous reviewers for their critical reviews. This study was supported by research fund of Chosun University, 2009.

\section{References}

Abd-El-Khalick, F., Bell, R.L., and Lederman, N.G., 1998, NOS and instructional practice: Making the unnatural natural. Science Education, 82, 417-436.

Abd-El-Khalick, F. and Lederman, N.G., 2000, Improving science teachers' conception of nature of science: A critical review of the literature. International Journal of Science Education, 22, 665-701.

Adams, P.E. and Krockover, G.H., 1997, Beginning science teacher cognition and its origins in the preservice science teacher program. Journal of Research in Science Teaching, 34, 633-653.

American Association for the Advancement of Science., 1993, Benchmarks for science literacy. Oxford University Press, NY, USA, 448 p.

Bianchini, J.A. and Cavazos, L.M., 2007, Learning from students, inquiry into rractice, and participation in professional communities: Beginning teachers' uneven progress toward equitable science teaching. Journal of Research in Science Teaching, 44, 586-612.

Bybee, R.W., 2000, Teaching science as inquiry. In Minstrell, J. and van Zee, E.H. (eds.), Inquiring into inquiry learning and teaching in science. American Association for the Advancement of Science, Washington, D.C., USA, 20-46.

Choi, J-R., Lee, S-K., Kim, C-J., Yu, E-J., Kim, J-H., and Oh, H-S., 2009, A case study on reflection-in-practice in science teaching's teaching changes. Journal of the Korean Association for Science Education, 29, 793-811.

Chung, W-W., 1998, An analysis and survey of experimental and practical education in high school earth science. Journal of Korean Earth Science Society, 19, 439448

Crawford, B.A., 1999, Is it realistic to expect a pre-service teacher to create an inquiry-based classroom? Journal of Science Teacher Education, 10, 175-194.

Crawford, B.A., 2000, Embracing the essence of inquiry: New roles for science teachers. Journal of Research in Science Teaching, 37, 916-937.

Kim, H. and Song, J., 2004, The exploration of open scientific inquiry model emphasizing students' argumentation. Journal of the Korean Association for Science Education, 24, 1216-1234.

Krajcik, K., Blumenfeld, P.C., Marx, R.W., Bass, K.M.,
Fredricks, J., and Soloway, E., 1998, Inquiry in projectbased science classrooms: Initial Attempts by middle students. The Journal of the Learning Science, 7, 313350.

Khishfe, R. and Abd-El-Khalick, F., 2002, The influence of explicit and reflective versus implicit inquiry-oriented instruction on sixth graders' views of nature of science. Journal of Research in Science Teaching, 39, 551578.

Kuhn, D., 1986, Education for thinking. Teachers college Record, 87, 495-511.

Kuhn, D., 1993, Science as argument: Implication for teaching and learning scientific thinking. Science Education, 77, 319-337.

Kwak, Y., 2009, Research on the effects of subject matter knowledge (SMK) on pedagogical content knowledge of secondary beginning science teachers in classroom teaching, Journal of the Korean Association for Science Education, 29, 611-625.

McCarthy, C.B., 2005, Effects of thematic-based, hands-on science teaching versus a textbook approach for students with disabilities. Journal of Research in Science Teaching, 42, 245-263.

Lederman, N.G., 1992, Students' and teachers' conceptions about the nature of science: A review of the research. Journal of Research in Science Teaching, 29, 331-359.

Luft, J.A., 2001, Changing inquiry practice and beliefs? The impact of a one-year inquiry based professional development program on the beliefs and practices of secondary science teachers. International Journal of Science Education, 23, 517-534.

National Research Council, 1996, National science education standards. National Academy Press, Washington, D.C., USA. 262 p.

National Research Council, 2000, Inquiry and the national science education standards. National Academy Press, Washington, D.C., USA, 410 p.

Osborne, J., Collins, S., Ratcliffe, M., Millar, R., and Duschl, R., 2003, What "Ideas-about-Science" should be taught in school science? A Delphi study of the expert community. Journal of Research in Science Teaching, 40, 692-720.

Park, M., Lee, J., Lee, G., and Song, J., 2007, Conceptual definition and types of reflective thinking on science teaching: Focus on the preservice science teachers. Journal of the Koreaa Association for Science Education, 27, 70-83.

Park, Y-S., 2006, Theoretical study on the opportunity of scientific argumentation for implementing authentic scientific inquiry. Journal of Korean Earth Science Society, 27, 401-415.

Park, Y-S., Kim, Y-S., and Park, S., 2010, Analysis of earth science textbook and beginning teachers' percep- 
tion \& practices with the view of ASI (Authentic Scientific Inquiry). Biannual conference of Korean Earth Science and Society, March $26^{\text {th }}$, Chungnam National University, p. 14.

Roehrig, G.H. and Luft, J.A., 2006, Does one size fit all? The induction experience of beginning science teachers from different teacher-preparation programs. Journal of Research in Science Teaching, 43, 963-985.

Smith, C.L., Maclin, D., Houghton, C., and Hennessey, M.G., 2000, Sixth-grade students' epistemologies of science: The impact of school science experiences on epis- temological development. Cognition and Instruction, 18, $349-422$.

Song, J. and Cho, S.-K., 2004, Research article: Yet another paradigm shift?: From 'Minds-On' to 'HeartsOn'. Journal of Korea Association for Science Education, 24, 129-145.

Yang, I., Kim, S., and Cho, H., 2007, Analysis of the types of laboratory instruction in elementary and secondary schools science. Journal of Korean Association for Science Education, 27, 236-241. 


\section{Appendix}

\section{Inquiry classroom 1}

The students engaged in an investigation initiated by significant student interest. A student asked what happened to the water in a watering can. The can was almost full on Friday and almost empty on Monday. One student proposed that Willie the pet hamster had left his cage at night and drunk the water. Encouraged by the teacher to find a way to test this idea, the students covered the water so Willie could not drink it. Over several days they observed that the water level did not drop. The teacher then challenged the students to think about other explanations. The students' questions resulted in a series of full investigations about the disappearance of water from the container. The teacher employed strategies such as asking students to consider alternative explanations, using evidence to form their explanation, and designing simple investigation to test an explanation. The science teacher never did explain evaporation and related concepts.

\section{Inquiry classroom 2}

Students investigated batteries and bulbs to learn about electricity. The teacher gave teams of students a battery, a bulb, and a piece of wire. To begin, the teacher told the students to use the materials and to "light the bulb." In time, the students lit the bulb and made observations about the arrangement of the battery, the wire, and the bulb. The teacher then provided other batteries, wires, small buzzers, and other materials and asked the students to explore different arrangement and see what they could learn. As the students continued their activity, the teacher pointed out certain results of their battery, bulb, wire, and buzzer systems. After several days of exploration with the materials, the teacher introduced the ideas that (1) electricity in circuits can produce light, heat, sound, and magnetic effects; (2) electrical circuits require a complete loot through which an electrical current can pass; and (3) electrical circuits provide a means of transferring electrical energy when hear, light, and sound are produced. In the end, students learned some basic ideas about electricity.

\section{Inquiry classroom 3}

In this classroom, the students selected from among several short stories that provided discussions of scientists and their work. Stories included Louis Pasteur, Marie Curie, Jonas Saik, and Barbara McClintock. Over a three-week period, every student read one of the stories as homework. Then, in groups of three, all student groups discussed and answered the same questions: "What questions did the scientist ask?" "What type of investigations did the scientist conduct?" "What instrument and equipment did the scientist sue?" "How did the scientist use observations to answer his or her questions?" After reading the stories and completing the discussion questions, the teacher had the groups prepare oral reports on the topic "how scientists do their investigation." 